\title{
Chapter 4 \\ Conformism or Inadequacy of Roma Inclusion Policies? Missed Opportunities at the European and Local Levels
}

\author{
Tina Magazzini, Enrica Chiozza, and Monica Rossi
}

\subsection{Introduction}

The Roma in Europe have been the object, over the past centuries, of a variety of (mostly discriminatory) policies, and more recently the target of integration strategies into mainstream (majority) societies. After experiencing a relative bettering of standards of living from the 1960s to the 1970s and 1980s, in the last two decades we have witnessed a general rise in the levels of both socio-economic exclusion ${ }^{1}$ as well as of anti-Roma sentiments on behalf of majority populations (Kovats 2001; Sigona and Treheran 2009). The Roma minority attracted significant European funds and attention over the past decade, the clearest expression of which has been the creation of policies that explicitly (even though not exclusively) target these groups. The policies that have been put into place so far, however, do not seem to have significantly bettered the situation, or at least not to the desired levels.

To understand why it is so, this chapter offers a brief overview of the EU soft policies in the field of Roma integration, and a look at how these efforts have translated into actions and programmes. Through the concrete case of ROMACT, we point at some of the hurdles and obstacles that are responsible for the so-called "implementation gap" (Stone 2001) of Roma integration measures.

\footnotetext{
${ }^{1}$ The precarisation and worsening of working conditions is by no means limited to Roma individuals, but members of Roma groups have been particularly and disproportionally affected by Central and Eastern Europe's shift to neoliberal market economies.

T. Magazzini $(\varangle)$

Robert Schuman Centre for Advanced Studies, European University Institute, Florence, Italy

e-mail: tina.magazzini@eui.eu

E. Chiozza

European Commission, Brussels, Belgium

e-mail: enrica.chiozza@europa.ec.eu

M. Rossi

Mayor's Cabinet, Municipality of Rome, Rome, Italy

e-mail: monicrossi@alice.it
} 
Our departing point is that Europe's freedom of movement played an important role in the development of political interest on this topic. During the years immediately following the 2004 and 2007 EU enlargements, the concern about the potential migration of impoverished Roma from Central and Eastern European countries to wealthier European Member States triggered measures towards marginalized Roma on behalf of many EU-15 countries. These measures, in turn, compelled European institutions to develop guidelines for the inclusion of Roma, defined as a general ethnic category. ${ }^{2}$

Already in the mid-1990s, a small group within the European Commission had attempted to bring the issue of widespread discrimination against Romani individuals and groups to the forefront of the discussion. An internal exchange between European Commission officers in 1996 reads:

\begin{abstract}
You know that I have been working rather hard at raising awareness inside the Commission and also on a wider front about the situation of the Roma particularly in central and eastern Europe but elsewhere too. Largely through my instigation, the Parliament is hosting a round table this 12th July and Nicolae Gheorghe will be interviewed by Europe Today. The problem is how to continue the work especially after I am gone. Whilst it is true that a number of individuals like myself [...] have taken a close interest in this and been extremely supportive, I don't think we can go on working informally without backing from a political level. Indeed 'my' informal working group has been the subject of some mild criticism from colleagues. [...] It is my view, rightly or wrongly, that this issue is a potential time bomb and that, in its own way, is a form of treatment for these people, which is at times blatant and intolerable racism. When it comes to accession negotiations, it may prove to be a stumbling block if it is not addressed now. (Extract of an email sent on 9 July 1996, provided to the authors by the sender)
\end{abstract}

While such warnings did not translate into any major political action on behalf of European institutions in the 1990s, the presence of considerable Roma minorities in central and eastern European countries did indeed prove to be a heated topic of discussion one decade later, during accession talks. The international dimension alone would however leave us with an incomplete picture, since the interplay between the different levels of policy (European, national, and local) proved just as important. While the international dynamics accelerated the political concern about the situation of Roma minorities in the early 2000s at the EU level, as showed by Nuno Ferreira in this volume, the EU power in the field of minority protection and promotion is limited. In practice, this means that the local implementation of policies and practices is where, ultimately, the success or failure of integration measures lie.

This chapter is therefore structured in the following way: we will start by giving a bird's eye view on how the EU policies in the field of Roma inclusion developed as a European concern, then make a case for the relevance of data collection, move on to analyse the use of Structural Funds in this field, and conclude by looking at the

\footnotetext{
${ }^{2}$ The EU for National Roma Integration Strategies adopted in 2011 by the European Commission employs the term "Roma" the same way as it did in the 2010 Commission Staff Working Document 'Roma in Europe: the Implementation of European Union Instruments and Policies for Roma Inclusion': "as an umbrella which includes groups of people who have more or less similar cultural characteristics, such as Sinti, Travellers, Kalé, Gens du voyage, etc. whether sedentary or not" (SEC(2010)400).
} 
importance of administrative capacity-building at the local level through the ROMACT case.

\subsection{The Marginalized Roma: A European Union "Issue"}

In December 2007, the European Council invited Member States and European institutions to use all means available to improve Roma inclusion. To this end it invited the European Commission to examine existing policies and instruments and to report to the European Council on the progress achieved before the end of June 2008. In July 2007 the European Commission published the Communication on non-discrimination and equal opportunities as a renewed commitment to combating discrimination through both legislative and policy tools (European Commission 2008b). This represented a first official acknowledgement that better tools were needed to promote Roma inclusion. The widespread unemployment and dramatic living conditions in which many Roma were (and still are) living were declared unacceptable from a fundamental rights perspective, as well as from a social cohesion standpoint (Thorbjørn 2015).

In 2008 the European Commission committed to achieving progress at European and national levels in key areas, such as awareness raising, non-discrimination mainstreaming, positive action and data collection, in collaboration with civil society and social partners. Data showed that Roma were unemployed by margins that were hardly comparable with majority populations, and that amongst those employed, Roma were overrepresented in occupations that involved underemployment or exploitative occupations in the informal economy. The discussion triggered by the ten Common Basic Principles drafted in 2009 by the European Commission represented an important push for all the successive actions taken by the Council of Europe, the Fundamental Rights Agency, the OSCE office for Democratic Institutions and Human Rights, the OCSE High Commissioner on National Minorities and other international organizations in support of Roma communities, especially the marginalized ones. The agreed upon ten Common Basic Principles were:

\section{The Ten Common Basic Principles on Roma Inclusion}

1. Constructive, pragmatic and non-discriminatory policies;

2. Explicit but not exclusive targeting;

3. Inter-cultural approach;

4. Aiming for the mainstream;

5. Awareness of the gender dimension;

6. Transfer of evidence-based policies;

7. Use of European Union instruments;

8. Involvement of regional and local authorities;

9. Involvement of civil society;

10. Active participation of the Roma. 
Further coordinated efforts were however needed to extend the scope of the Roma issue - mostly treated at the European level as a pure equality and antidiscrimination issue - to include an explicitly socio-economic angle.

In this regard, the inclusion of Principle 8 ("Involvement of regional and local authorities"), Principle 9 ("Involvement of civil society") and Principle 10 ("Active participation of the Roma") were strategic to trigger a more active involvement of Member States and regions by making Structural Funds available. ${ }^{3}$

The "Roma issue" slowly started becoming a shared responsibility between the European Union institutions, Member States and regions. Against this background, the Structural Funds constituted the main financial tool available to design and to implement actions in support of Roma integration at the local level. The funds' regulations did not, however, explicitly target Roma communities, nor did it provide data, guidance or good practices on how to design effective programmes and projects. In short, due to the principle of subsidiarity, no concrete way could be put in place to exercise leverage toward those Member States that might use the tools and funds ineffectively. This "enforcement blind-spot" created, and continues to create, a gap between the intentions expressed in EU planning documents and their translation into effective and measurable policies and programmes.

\subsubsection{Data Collection for Evidence-Based Policy Development}

In 2010, the Open Society Foundations (OSF) published a report outlining the situation of data collection in the Roma Decade countries ${ }^{4}$ and pointing at the fact that progress is difficult to achieve-and impossible to measure-in the absence of reliable data (Open Society Foundations 2010).

To date, as highlighted by Vera Messing in this volume, important gaps remain on the data that is available regarding the employment, level of education, housing and healthcare of Roma versus non-Roma citizens. The reasons for the lack of data vary: in some cases, the national legislation forbids to collect census or administrative data based on ethnicity; in other cases, data is collected but only partially; in yet other countries there is more freedom in data collection, but restrictive data protec-

\footnotetext{
${ }^{3}$ Article 158 of the Treaty establishing the European Community states that, in order to strengthen its economic and social cohesion, the Community aims at reducing disparities between the development levels of the various regions-although it could be argued that, in practice, EU fiscal consolidation and austerity policies have produced effects in the opposite direction. Article 159 of the Treaty requires actions aimed at reducing regional inequalities to be supported by the Structural Funds, which can be used to promote equality and combat discrimination, including racial and ethnic discrimination.

${ }^{4}$ The countries which were part of the 2010 Decade on Roma inclusion are: Albania, Bosnia Herzegovina, Bulgaria, Croatia, Czech Republic, Hungary, Former Yugoslavian Republic of Macedonia, Montenegro, Romania, Serbia, Slovakia and Spain.
} 
tion legislation limits the access to such data in practice. Unfortunately, the consequences of reliable hard data on how Roma fare, comparatively to non-Roma, are similar in all countries: the investments aimed at improving the socio-economic conditions of marginalized Roma groups, when and where they take place, are carried out based on perceptions rather than on measurable indicators, and no impact assessment can be carried out. ${ }^{5}$ The result is that policy-makers rely on general Council of Europe estimates, often to design policies on poverty migration or on socio-economic inclusions that they want to carry out anyways for political reasons, without stemming from actual evidence of a policy need.

For some years now, reports published by several international organizations have raised the alarm about the poor life conditions in which many Roma live, and the violations of the fundamental rights they suffer from. Such reports however offer very limited disaggregated and comparable data to localize and address the problem (Fundamental Rights Agency 2009; UNDP 2003). What is missing is therefore a formalized and structured dataset that would allow for the creation of composite indicators. One effort to remedy such knowledge-gap was a joint project launched by the European Commission in 2010 in partnership with the World Bank, the United Nations Development Programme and the Fundamental Right Agency aimed at collecting data on the socio-economic aspects of marginalized communities. The project was carried out in 11 European Member States and in neighbouring countries with surveys which identified the differences in living standards and in access to services between Roma and non-Roma families, all of whom lived in "marginalized" areas (Fundamental Rights Agency and UNDP 2012). ${ }^{6}$ By adopting a residential approach, the survey moved the focus away from a purely ethnic-based counting and profiling - which encounters obstacles in the legislation of many European member states. The evidence collected could thus be used for an "explicit though not exclusive" evidence-based policy in support of marginalized Roma communities in such localities, yet, in doing so, it also stressed the socio-economic marginalized condition of the Roma groups targeted by the study, with the risk of reinforcing an "ethnic" imagery that overlaps with one of "deprivation". Moreover, the use of quantitative indicators and of surveys, if taken at face value, have been widely criticized (Rossi 2016).

What might offer a more balanced source for information on which to base policy design is triangulating a range of different methods, such as those employed by the cited pilot study, combined with more ethnographic approaches and with social services datasets. In 2001, for instance, the European Council agreed on a list of

\footnotetext{
${ }^{5}$ Measuring the impact of programmes and policies is a requirement for ESIF funds 2014-2020, nonetheless in many countries (notably southern Europe) there is a certain resistance to the adoption of such procedures. The same can be said about the feasibility studies that must be carried out before implementing the interventions, which are crucial when it comes to planning policies and programmes.

${ }^{6}$ The 11 EU Member States where the survey was conducted were Bulgaria, Czech Republic, Greece, Spain, France Hungary, Italy, Poland, Portugal, Romania, Slovakia.
} 
social indicators to guide the fight against poverty. If such "Laeken" indicators were to be adopted by Member States, they could represent a good opportunity to design and implement more evidence-grounded policies (European Commission 2008a) to monitor the evolution of Roma disadvantage over time and in different European territories.

\subsection{The European Parliament Pilot Project on Marginalized Roma Inclusion: Defining the Problem and Identifying Areas of Action}

In the European Union context, the European Parliament was a decisive actor in starting a discussion on Roma socio-economic inclusion and antidiscrimination. In 2009, the European Parliament entrusted the European Commission Directorate General for Regional and Urban policy with a pilot project ${ }^{7}$ whose objective was to explore innovative and integrated approaches to tackling the multidimensional problems facing Roma groups. The project explored ways in which Roma inclusion could be promoted, mainly through education and microfinance initiatives. It also proposed new methods and tools for data collection, monitoring and evaluation. These tools would ultimately represent the baseline for evidence-based policy development in the field of socio-economic inclusion of marginalized Roma in five EU Member States: Hungary, Slovakia, Check Republic, Romania and Bulgaria.

The project undertook a careful review of the early learning environment faced by Roma children at home, in their neighbourhoods and at school, including a review of national policies and local programs. In particular, new evidence showed that the gap in access to learning opportunities starts early. While more than $75 \%$ of all children aged 3-6 were in preschool during the years covered by the study (2010-2012), the large majority of Roma children were not. In Bulgaria only 45\%, in Romania 37\%, in the Czech Republic 32\%, and in Slovakia 28\% of Roma children aged 3-6 were in pre-school. The outlier amongst the five countries was Hungary, where preschool is compulsory and where the government supports poor families by covering out-of-pocket expenses and school lunches, which resulted in $76 \%$ of Roma children being enrolled in preschool (World Bank 2012). However, in spite of anti-segregation laws, Roma pupils are still often subjected to school segregation and they are vastly overrepresented in the category of "pupils with special needs" in all of the above-mentioned countries.

The Roma pilot project also assessed the scope for leveraging microcredit schemes to increase self-employment, with the ultimate goal of reducing the large employment gaps between Roma and non-Roma. The findings pointed at the num-

\footnotetext{
${ }^{7}$ The European Parliament pilot projects are defined as schemes of an experimental nature designed to test the feasibility of an action and its usefulness.
} 
bers of self-employed Roma being relatively low, even though many of the participants expressed interest in becoming self-employed ${ }^{8}$ (The World Bank 2012). Unsurprisingly, the vast majority of unemployed Roma and non-Roma expressed a desire for stable jobs, ${ }^{9}$ and many of the Roma participants expressed an interest in starting a business. However, most Roma interested in becoming self-employed faced significant obstacles in accessing the credit to start a business. One issue is that not many suppliers of microfinance loans target start-up businesses in general, and even fewer are reaching Roma entrepreneurs. A key reason is that many potential Roma entrepreneurs do not qualify for credit in light of lack of savings or indebtedness, low levels of education (even when compared to the segment of the general population that is being refused credit) and lack of employment experience in the formal economy. In short, what would be needed is a comprehensive approach to financial inclusion that goes beyond strictly providing microcredit and tackles multifaceted obstacles-limited outreach of financial service providers in Roma neighbourhoods, lack of access to savings technology, low financial literacy, and so on. In the absence of such a comprehensive approach, there is little hope for improvement.

Related to the residential dimension, the employment dimension emerged to be strongly intertwined to the housing one: both "involuntary segregation" and institutionalised forms of segregated housing (such as the encampments in Italy) represent huge obstacles to any kind of integration action.

Last but not least, the project identified the need for a holistic and comprehensive approach towards Roma socio-economic inclusion. Combining interventions across more than one of the identified critical areas is essential, as it is to set objectives and priorities in order to avoid incoherence, the fragmentation of activities and unsustainability of the approach. The customization of interventions to specific local needs and the involvement of the community (both Roma and non-Roma) also proved to be essential elements for a sustainable and effective socio-economic inclusion.

The project identified that the cycle of poverty is reinforced by frequent segregation - in housing but also schooling - misperceptions, and discrimination, which go hand in hand with high levels of unemployment. In short, for the first time a project pointed with data at the fact that Roma suffer from multiple, interlinked vulnerabilities. As a result, raising the employment rates amongst Roma was identified as an economic necessity for Eastern European countries and a priority for the EC. ${ }^{10}$

\footnotetext{
${ }^{8}$ Among the employed Roma, the share that is self-employed is low in the Czech Republic, Hungary, and Slovakia, while noticeably higher in Bulgaria and Romania.

${ }^{9}$ This data reflects the statements of the interviewees, which can however be contested on the basis that there is little proof of job-seeking attempts.

${ }^{10}$ According to de Laat (2010), while majority populations are aging, approximately 7-20\% of new labor market entrants in Bulgaria, the Czech Republic, Hungary, Romania, and Slovakia are Roma.
} 


\subsubsection{The European Structural Funds 2007-2013}

A 2008 staff-working document that accompanied the above-mentioned Communication underlined the enormous potential that the Structural Funds and the pre-accession instruments hold. It also identified specific measures to be implemented at the Member States level such as capacity-building of local administrations, project monitoring and participation of the stakeholders. However, during the negotiation of the Structural Funds 2007-2013 the potential of this unique investment tool was only partially earmarked for Roma inclusion. The main pitfall of this integrated approach laid in the distribution of those funds that were going to indirectly target Roma communities among six different operational programmes. Out of the initial impressive allocations, only about one fourth were eventually spent, and no requirements were in place during that programming period that allowed the European Commission to monitor how many Roma benefited from the interventions, and in which localities.

The high ambitions set at the European level were met with significant obstacles at the implementation level in local contexts. The most common difficulty had to do with the lack of administrative capacity, scarce involvement of Roma beneficiaries, and no strong political will nor commitment on behalf on the mayors or regional administrators. In this programming period, as had happened in other occasions, the exception was Spain, with a Roma population of approximately 750,000 (Ministerio de Sanidad Servicios Sociales e Igualdad de España 2012). Spain, where Roma suffer a comparatively limited level of marginalization, was able to coordinate the implementation of the Structural Funds, in particular the European Social Fund, in a quite effective way. Capacity-building and a territorial approach, coupled with a receptive and overall non-discriminatory society helped the national and regional authorities in the eradication of slums, the enrolment of kids in schools, and schemes to increase skills of unemployed Roma. The success of the Spanish example is also linked to the Secretariado Gitano, an independent foundation created in 1982 which is very well rooted in the different autonomous regions and is able to push both the national and regional authorities to take action on the basis of consolidated strategies and action plans. Despite the strong presence of the Secretariado Gitano and of numerous other Gitanos associations, which could lead to think that the key to Spain's (at least relative) success lays in the fact that it has taken a specific approach, however, the main Spanish achievement with regard to its Roma population arguably lays in the mainstreaming of inclusion policies (Kostka 2015). The housing and education reforms carried out during the 1980s, in particular (way before the 2012 National Roma Integration Strategies), rendered social housing and public education widely available to the most marginalized sectors of the population, of which the Roma happened to be a large component. Similar initiatives took place in Italy during the 1970s, with the destruction of historical shanty towns and with the access to social housing of a large part of the population (including many Italian Roma) who were previously living in precarious and marginal settings, but this trend was unfortunately reversed with the creation of encampments for (especially foreign) Roma. 
How and why was this possible? Without dismissing the criticism of the shortcomings that have emerged on the so-called "Spanish model" (Ovalle and Mirga 2014), the focus in the Spanish case has always laid in poverty and in socioeconomic marginalization, which has been therefore tackled through povertyeradication measures that tend to be less controversial than those regarding cultural diversity. ${ }^{11}$

\subsubsection{The National Roma Integration Strategy as Precondition for the European Structural and Investment Funds Investments}

As we saw in the previous sections, between 2010 and 2011 some progress was made at the European policy level. The Roma agenda was high in the European Commission priorities and both the European Commission and the European Parliament started to gather some evidence on the dramatic situation of Roma in Europe. In April 2010 (the 7th of April, one day before the second Roma Summit was held in Cordoba during the Spanish Presidency) the European Commission adopted a Communication on the social and economic integration of the Roma in Europe (European Commission 2010). This was the first official recognition that the "Roma issue" was not only a matter of discrimination, but also of social cohesion, and that allowing the situation to deteriorate for an already vulnerable sector of the population would have wide negative economic and social implications on society as a whole. Such acknowledgement and the active implication of European institutions did not however emerge from economic preoccupations alone, nor would they have emerged with such force in the absence of a dramatic trigger. On the 30th of August 2010, ${ }^{12}$ the French government announced that 128 "illegal settlements" had been dismantled and that the Roma families who inhabited them were going to be returned to Romania and Bulgaria, either voluntarily or by force, due to their irregular situation in France. Reactions from several international and European institutions and NGOs pushed the European Commission to act, in order to prevent an escalation of the phenomenon. On the 5th of April 2011 a breakthrough Communication was adopted by the European Commission calling on Member States to present each a National Roma Integration Strategy, and to create Roma National Contact Points by the end of December 2011 (European Commission 2011). France, while claiming that it is unable to design and carry out a strategy based on ethnic profiling, agreed to present a strategy which would address issues of discrimination and poverty.

\footnotetext{
${ }^{11}$ This issue is however different for those non-Spanish Roma that recently migrated to Spain, and who are experiencing harsh difficulties in integrating (Magazzini and Piemontese 2016).

${ }^{12}$ For more details, see the «Communiqué faisant suite a la reunión ministerielle de ce jour sur la situation des gens de voyage et des Roms»: http://medias.lemonde.fr/mmpub/edt/doc/20101021/1 429059_2147_2romscommuniqueelysee28juillet.pdf
} 
While the European Framework for National Roma Integration Strategies saw some delays, it has been for the past 7 years a major reference for European Roma inclusion policy. What makes it noteworthy-apart from the fact that it is the most ambitious and wide-ranging inclusion policy addressed at Europe's Roma minority-is its funding provisions. The way in which the Framework was designed links it to the European Structural and Investment Funds, and in particular to the European Regional Development Fund (ERDF) and the European Social Fund (ESF). While said funds generally require some level of co-funding on behalf of national or local authorities, they however represent a significant asset which hold the potential of developing inclusion policies which would otherwise not be feasible.

As of 2019, it is still premature to assess the impact that the European framework has had on the structural funds investments programmes. The major and most persistent obstacle, in practical terms, seems to be the lack administrative capacity at the local level. Mindful of such challenge, the European Commission (in partnership with the Council of Europe) launched in 2012 a pilot initiative-ROMACTaimed at strengthening the skills of local administrators in dealing with European-related projects, with the involvement of local NGOs and of Roma communities. The ROMACT project has been now ongoing for 6 years and is currently being implemented in six EU Member States (Slovakia, Romania, Bulgaria, Italy, Hungary, and Check Republic), but has so far led to mixed results. The following section is therefore devoted to analysing a bit more in depth such programme, raising some of the issues that remain to be solved.

\subsection{ROMACT: Administrative Capacity at the Local Level}

There is widespread agreement amongst researchers and experts who have been engaged with the "Roma issue" over the last decade that one of the main factors hindering the inclusion of this minority at the local level has been the lack of political commitment and an adequate administrative capacity. This interpretation requires however some nuance, if we are to understand what has worked and what has not, and to propose new viable ways forward.

As mentioned, the ROMACT Programme is a joint initiative implemented by the Council of Europe and financed by the European Commission, which aims at promoting the inclusion of Roma at local and regional level. Stemming from the conviction that the involvement of local authorities in the integration of their Roma residents is pivotal to bettering living standards, ROMACT was presented as a programme which could finally offer concrete practical help to local administrations, by strengthening their capacity to design and implement viable projects for Roma inclusion. The program explicitly aimed to contribute in this way to the implementation at local level of the National Roma Integration Strategies: its mandate is to reinforce the capacity of local authorities and to help develop and support those mechanisms and processes that can better the implementation participatory planning processes. 
The participation of Roma stakeholders to policy-making that affects them has been widely advocated from Roma organizations and EU institutions alike, and it is only natural that it would constitute a prerequisite of the local policies. Yet, the translation of this principle (which was also included as a methodological indication in the National Strategies) into actual policy has proven to be often complex in the absence of clear tools or devices to assess who and how to include in such processes. In order to effectively guarantee a real Roma participation, rather than producing a mere rhetoric of Roma representation, there must be some degree of "homogeneity" or shared interested among group members, as well as accurate information available about what European funding is available, what kind of constraints it entails, and what the options available are in terms of viable and sustainable projects. In countries such as Italy, for instance, where many stakeholders are either illiterate or lack the information regarding what the National Roma Integration Strategy means and involves, their participation to National, Regional and local tables has resulted in generalized failure. The risk is therefore that fostering Roma participation without actively supporting the tools necessary to actively engage in the process and put forward proposals that can be financed may induce a doublebinding effect. ${ }^{13}$

Political participation and engagement are elements that typically arise either from cultural emancipation through education, or from within the working context (such as unions). ROMACT, instead, so far seems to have adopted a "minority rights to diversity" approach, avoiding framing the marginality issue in terms of urban poverty. The choice of the Eastern and Central European model of integration, which bears similarities with the Anglo-Saxon communitarian perspective based on identities and on a stress on diversity, has replaced a more universalistic approach to goods and services. In practice, this has shifted the language from class to race or ethnicity and framed the focus of Roma integration in terms of "culture" and "ethnicity". This approach is however built upon a Framework which, as outlined above, is mainly concerned with access to services and with socio-economic disadvantage.

This might be the reason why the ROMED-ROMACT programme has so far offered mixed results and has performed particularly poorly in Italy. In Italy, public administrators of large cities were not eager to join the program. The team and the methodology itself failed to attract interest among city authorities and the main interventions have been limited to small towns. Such failure should not be considered exclusively as an indicator of the lack of administrative capacity of local authorities, but it suggests that the ROMACT-ROMED programme, as presented, was not seen as an asset by those administrators that were supposed to benefit from it. One reason for this, other than the widespread reluctance to engage with Roma

\footnotetext{
${ }^{13}$ The Roma Plan for Rome (Deliberazione Giunta Capitolina n. 105, 26 Maggio 2017, Piano di Indirizzo di Roma Capitale per l'inclusione delle Popolazioni Rom, Sinti e Caminanti) was preceded by a 2-month phase of consultations with Roma NGOs. A list of Roma NGO was offered by UNAR (Italian Equality Body) and the Plan was sent to them for observations. However, not one single viable proposal emerged from this short survey. Contributions were for the larger part either critiques that did not propose alternative projects; or invitations to involve their own NGO in projects which were not sustainable, such as the idea to create Roma cooperatives for the copper trade.
} 
inclusion (as a topic which is unpopular with the electorate) is the idiosyncrasy between the need for technical help for anti-poverty policy design and monitoring on the one hand, and the focus of cultural recognition on the other. Additionally, the approach of the Council of Europe representatives has been interpreted at times as a confrontational one, rather than one offering professional support in project management. On the ROMACT website, the main issue to be tackled appears to be Antigypsysm, lamenting "paternalistic attitudes on the side of the local authorities, who tend to consider that they know better what Roma need and discount the possibility of a real dialogue, often combined with an attitude of dependency and acceptance on the side of the Roma community members; mutual mistrust and mutual blaming between Roma and public institutions". While such attitudes, where present, certainly constitute an obstacle to constructive engagement and inclusive policies, the generalised assumption that local authorities tend to be racist can in itself foster a negative blaming-cycle which only reinforces mutual distrust.

Some issues may also result from the misconceptions or partial understandings that stem from taking at face value the available surveys or interviews on the aspirations and plans of those Roma who live in segregated camps. Such data invariably paints a picture in which all Roma want to leave the encampments and gain access to apartments (European Union Agency for Fundamental Rights 2011, 2016), if it weren't for financial constraints. The picture is rendered however more nuanced by the fact that, in some cases, certain families prefer to remain in the camps even if according to the municipality their economic situation would allow them to rent an apartment (HuffPost 2017). Such choices can have multiple causes, ranging from the difficulty in renting an apartment (because of discrimination from private houseowners) to cultural norms, preferences or traditions (many Sinti in northern Italy have applied for micro-areas rather that apartments), to engrained dynamics that make it difficult for individuals to leave a known reality.

Another potential risk of the ROMACT approach, if used as an advocacy tool rather than a technical resource, is that it has on occasions contributed to spread the idea that there are certain resources earmarked for Roma inclusion at the European level that can be mobilized at will, while all European funding still requires national or local co-funding and an evaluation-based application process (Corriere della Città 2017). Additionally, even once resources have been allocated in the Programming Arrangements (PA) and in the following Regional Operational Programming (ROP), the schemes can be changed even after these have been issued, and interventions can always be re-programmed, which means there must be a continued and consistent commitment to Roma integration in order for the implementation phase to be carried out as initially planned. Italy's Lazio Region, for example, declared that it would invest a certain sum in Roma inclusion within the Regional Operational Programming 2014-2020 under Thematic Objectives (OT) 9 and $10 .{ }^{14}$ These resources were however substantially diminished in a second phase, and Roma inclusion has since more

\footnotetext{
${ }^{14}$ OT 9 was 'Promoting social inclusion, combating poverty and any discrimination', while OT 10 was 'Investing in education, training and vocational training for skills and lifelong learning'. See http://ec.europa.eu/regional_policy/en/policy/what/glossary/t/thematic-objectives
} 
or less vanished from the Regional Agenda, in spite of what stated in official documents. Finally, one additional note of concern which, at least in Italy, has become associated to the ROMACT programme, is the lack of definition of what skills are required to be considered a "Roma inclusion specialist", with the risk of ethnic categorization and tokenism being adopted by either single individuals or NGOs who see this as a funding opportunity. In this sense, the fact that the National Project Officer of ROMACT in Italy happens to be a well-known Roma activist who, while appointed as ROMACT's National Programme Officer, was at the same time campaigning for a national law to recognize Roma in Italy as a linguistic minority, has not helped. The risk, in such a situation, is that on the one hand local authorities end up with all the blame for failing to include the Roma, and on the other hand it gives Roma a kind of "negative visibility" that no other group has, which in countries where Roma are a small, unrecognized minority, can exacerbate the already existing conflicts among Roma and non Roma, resulting in a negative effect on the social cohesion of the local territories and on increased Antigypsism.

Again, the issue of the reliability of data comes back as one of the most pressing. The use of an appropriate methodology for data-collection at ground level is of crucial importance, especially if this data is to be fed into the design and implementation of effective inclusion policies. The broad on-going discussions on what constitutes "truth" and "falsehood" in ethnography is out of the scope of this chapter, yet it is noteworthy that ethnographic studies and tools are too seldom used to feed into policy-making, which tend to rely to survey-data that is taken at face value instead. ${ }^{15}$ In this process, what often gets overlooked is that field data for applied use must be carefully interpreted to ensure that the inferences made stem from the daily observation of reality, even though this requires lengthier processes than simply constructing indicators based on unproblemised survey answers.

Ultimately, data used for policy-making must capture the picture of the field at the residential and neighbourhood level, and such in-depth knowledge cannot be acquired with short visits to the Roma dwellings nor with thematic interviews to their inhabitants alone. Such studies are at times presented as ethnographic inquiries, but they lack the central component of the ethnographic process, ${ }^{16}$ which is the engagement of the researcher combined with the direct and prolonged observation of social contexts. In our opinion this aspect is necessary to counterbalance the information that the informant is offering to the researcher, but the long timelines required for these types of studies to be carried out are almost always incompatible with the tight deadlines imposed on both researchers and international agencies. ${ }^{17}$

\footnotetext{
${ }^{15}$ The self-representation of subjects is an important part of any anthropological work, and in some cases, even a single life-history can be telling of the wider picture. See for example the representation of the Moroccan migration to Europe through a single life-history in Crapanzano (1980).

${ }^{16}$ This is why we should use the expression 'ethnographic process' rather than 'ethnographic technique'.

${ }^{17}$ For instance, the OECD came to Rome in 2016 to carry out "fieldwork visits" in Roma encampments and refugee reception facilities. Yet, all the data was collected over a 4-day visit in which the field visits consisted of approximately $1 \mathrm{~h}$ in each site, which can hardly allow to get a sense of the issues at stake.
} 


\subsection{Conclusions}

Over the past decades, the severe conditions and discrimination that Roma individuals suffered in Europe have created a EU internal phenomenon of so-called poverty migration. This has, in turn, triggered a political momentum and willingness to act on behalf of Western Europe Member States and of the European institutions at large. In France, for instance, some municipalities have started twinning projects with the municipalities of origin of Roma who migrated from Romania and Bulgaria. These initiatives are quite spontaneous and have resulted in small projects that, with the involvement of local NGOs, aim at improving the conditions of Roma in the municipalities of origin, and thus disincentive westward migration. However, the economic crisis and the increase in the number of at-risk-of-poverty population in several EU Member States (both Roma and non-Roma) has made Roma affirmative action quite unpopular. In countries with a high level of informal economy, such as Italy or Greece, the difficulty in carrying out ethnically-based policies has exacerbated conflicts among the Roma and non-Roma, and has on occasion resulted in contradictory policies at the local level. The result has been a series of fragmented initiatives, which on the one hand aim at promoting Roma integration to comply with EU guidelines, and on the other hand promote a "securitized" and policed approached which part of the electorate advocates for.

In this respect, there is little doubt that the interest of local authorities in Roma inclusion has often subsided to political concerns, and that structural discrimination in institutions (and not only among the electorate) is a component that must be accounted for. The position of this chapter is that, however, as has been argued elsewhere (Law and Kovats 2018) the focus on non-discrimination alone cannot address the entrenched inequality which characterizes the Roma situation in Europe.

In other words, in order to achieve concrete results, it is essential to bridge the gap between the EU and the local level. If from their side the EU and the national level can design and finance policies aimed at bettering the socio-economic situation of the too many Roma who find themselves in poverty, the local authorities have a responsibility to identify concrete projects that can be accepted and endorsed by both Roma and non-Roma residents. For this purpose, more work is needed to build local administrative capacity and to support local authorities in designing and implementing sustainable projects that can trigger a permanent change.

The lack of results, 6 years after the launch of the National Roma Integration Strategies and 5 years after the ROMACT programme, means that we must rethink the ways in which Roma integration has been approached and addressed. In order to do so, it is necessary for policymakers, EU institutions and NGOs alike to adopt new epistemological tools, abandoning a terminology that often does not reflect the dynamics on the ground. In short, new and fresh inputs into the Roma issue must nudge both pro-Roma organizations and local institutions to abandon an identity-based confrontational approach, and engage with practical, local-based 
solutions. These inputs should set the basis for a new solidarity among our globalized, mixed societies, bringing in a new spirit of citizenship rights and citizens' education, giving less space to the pro-ethnic approach that has dominated so far. The spirit that animated the ROMED-ROMACT programs is based on a vision that has, in practice and maybe unintendedly, reinforced particularities rather than fostered solidarity.

The issue of Roma integration must also be understood as part and parcel of a neoliberal approach that, rather than tackling generalised problems such as housing scarcity, treats minority disadvantage as an emergency situation. Housing and job precarity have however become a widespread normalcy for a sector of the population in which Roma individuals are overrepresented. In many countries, the European Structural Funds represent the sole available financial resource to achieve the objectives set out in the National Roma Integration Strategies by EU Member States, yet they often end up competing with the needs and claims of other marginalized groups. ${ }^{18}$

All this comes at a time in which Europe is struggling against centrifugal forces that are trying to undermine the long process of peace among and within nations. For these reasons, programmes and policies financed by the European Union should ensure the diffusion and adoption of universalistic values, or at least ensure that they are not perceived as promoting ethnic-based welfarism. What can be gathered from an assessment of the policies carried out so far is that a ROMACT project is indeed needed. The need is however for a ROMACT programme that carries out technical support, trying to avoid getting into politics or confrontation with local authorities. If such interventions manage to capitalize on the willingness of those municipalities that want to take advantage of European funds to achieve practical and durable solutions, then the EU soft policies efforts might indeed be of some practical use. The building blocks are set, it is now time to make sure that the money is spent on viable and sustainable projects, and that their implementation is adequately monitored. For such practical goals, we might need the help of ethnographers: as detailed accounts and in-depth understanding of the local dimensions and dynamics can provide ways forward where statistics alone cannot.

\section{Bibliography}

Corriere della Città. (2017). L'associazione dei Rom denuncia Roma Capitale per truffa: "spariti” $i$ soldi dei fondi europei. Roma. Retrieved from http://www.ilcorrieredellacitta.com/news/ nazione-rom-denuncia-roma-capitale-ad-anac-truffa.html

Crapanzano, V. (1980). Tuhami, portrait of a Moroccan. Chicago: Chicago University Press.

\footnotetext{
${ }^{18}$ The NRIS represent an ex-ante thematic condition to the use of funds in support of Roma marginalized communities.
} 
de Laat, J. (2010). World Bank -Europe and Central Asia: Economic costs of Roma exclusion economic cost of Roma exclusion calculating economic costs of Roma exclusion. The World Bank.

European Commission. (2008a). COM(2008) 418 final. A renewed commitment to social Europe: Reinforcing the Open Method of Coordination for social protection and social inclusion. Brussels.

European Commission. (2008b). Commission Staff Working Document accompanying the COM(2008) final 420 "Non-discrimination and equal opportunities: A renewed commitment. European Commission communication".

European Commission. (2010). Communication from the Commission to the Council, the European Parliament, the European Economic and Social Committee and the Committee of Regions. The social and economic integration of the Roma in Europe. Retrieved from http:// eur-lex.europa.eu/legal-content/en/ALL/?uri=CELEX:52010DC0133

European Commission. (2011). Communication from the Commission to the European Parliament, the Council, the European Economic and Social Committee of Regions. An EU Framework for National Roma Integration Strategies up to 2020. Retrieved from http://eur-lex.europa.eu/ legal-content/en/ALL/?uri=CELEX:52011DC0173

European Union Agency for Fundamental Rights. (2011). EU-MIDIS technical report. Methodology, sampling and fieldwork.

European Union Agency for Fundamental Rights. (2016). Second European Union minorities and discrimination survey Roma - Selected findings.

Fundamental Rights Agency. (2009). The situation of Roma EU citizens moving to and settling in other EU Member States. https://doi.org/10.2811/34658.

Fundamental Rights Agency, and UNPD. (2012). In Fundamental Rights Agency (Ed.), The situation of Roma in 11 EU Member States. Survey results at a glance. Luxembourg: Publications Office of the European Union. https://doi.org/10.2811/76056.

HuffPost. (2017). Roma paga il "mental coach" per convincere i rom a lavorare. Roma. Retrieved from http://www.huffingtonpost.it/2017/07/23/roma-paga-il-mental-coach-perconvincere-i-rom-a-lavorare_a_23043738/

Kostka, J. (2015). Implementation of Roma inclusion policies: Why defining the problem matters. Social Inclusion, 3(5), 78. https://doi.org/10.17645/si.v3i5.231.

Kovats, M. (2001). Problems of intellectual and political accountability in respect of emerging European Roma policy. Journal on Ethnopolitics and Minority Issues in Europe, 2(1), 1. Retrieved from http://www.ecmi.de/fileadmin/downloads/publications/JEMIE/2001/Focus112001KovatsComment.pdf

Law, I., \& Kovats, M. (2018). Rethinking Roma. Identities, politicisation and new agendas. London: Palgrave Macmillan.

Magazzini, T., \& Piemontese, S. (2016). Roma migration in the EU: The case of Spain between "new" and "old" minorities. Migration Letters, 13(2), 228-241.

Ministerio de Sanidad Servicios Sociales e Igualdad de España. (2012). Estrategia Nacional para la Inclusión Social de la Población Gitana en España 2012-2020.

Open Society Foundations. (2010). No data - No progress. Country findings.

Ovalle, O. M., \& Mirga, A. (2014). The myth of the Spanish model of Roma inclusion. Retrieved from https://www.opensocietyfoundations.org/voices/myth-spanish-model-roma-inclusion.

Rossi, M. (2016). La trappola dell'etnicità: gabbia e risorsa. Rome: Il Manifesto. Retrieved from http://ilmanifesto.info/la-trappola-delletnicita-gabbia-e-risorsa/

Sigona, N., \& Treheran, N. (Eds.). (2009). Romani politics in contemporary Europe: Poverty, ethnic mobilisation and the new liberal order. London: Palgarve Macmillan.

Stone, D. (2001). Getting research into policy? Third Annual global development network conference on "Blending Local and Global Knowledge" (Vol. 10). Rio de Janeiro.

The World Bank. (2012). Reducing vulnerability and promoting the self-employment of Roma in Eastern Europe through financial inclusion. Retrieved from http://www-wds.worldbank.org/ external/default/WDSContentServer/WDSP/IB/2012/09/06/000333037_20120906002654/ Rendered/PDF/723310WP0P127200financial0inclusion.pdf 
Thorbjørn, J. (2015). State of democracy, human rights and the rule of law in Europe. A shared responsibility for democratic security in Europe.

UNDP. (2003). Avoiding the dependency trap. Bratislava: United Nations Development Program. Retrieved from http://scholar.google.com/scholar?hl=en\&btnG=Search\&q=intitle:Avoiding+t he+Dependency+Trap\#1

World Bank. (2012). Toward an equal start: closing the early learning gap for Roma Children in Eastern Europe. Retrieved from http://siteresources.worldbank.org/EXTROMA/Resources/ RomaECD_FinalReport.pdf

Open Access This chapter is licensed under the terms of the Creative Commons Attribution 4.0 International License (http://creativecommons.org/licenses/by/4.0/), which permits use, sharing, adaptation, distribution and reproduction in any medium or format, as long as you give appropriate credit to the original author(s) and the source, provide a link to the Creative Commons licence and indicate if changes were made.

The images or other third party material in this chapter are included in the chapter's Creative Commons licence, unless indicated otherwise in a credit line to the material. If material is not included in the chapter's Creative Commons licence and your intended use is not permitted by statutory regulation or exceeds the permitted use, you will need to obtain permission directly from the copyright holder.

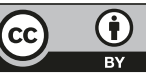

